\title{
Role of metal species in flocculation rate during estuarine mixing
}

\author{
${ }^{1}$ A. Biati; ${ }^{3}$ A. R. Karbassi; ${ }^{2}$ A. H. Hassani; ${ }^{1}$ S. M. Monavari; ${ }^{2}$ F. Moattar \\ ${ }^{1}$ Department of Environmental Science, Graduate School of the Environment and Energy, Science and \\ Research Branch, Islamic Azad University, Tehran, Iran \\ ${ }^{2}$ Department of Environmental Engineering, Graduate School of the Environment and Energy, Science and \\ Research Branch, Islamic Azad University, Tehran, Iran \\ ${ }^{3}$ Graduate Faculty of the Environment, University of Tehran, Tehran, Iran
}

Received 3 January 2010; $\quad$ revised 2 February 2010; accepted 28 February 2010; avaiable online 1 March 2010

\begin{abstract}
Flocculation can be considered as an effective mechanism in self-purification of metals during estuarine mixing. In the present investigation, flocculation of metals during mixing of Minab River water with the Strait of Hormuz (The Persian Gulf) water is studied for the first time. Flocculation behavior of metals (except for Pb) is governed by dissolved organic carbon. The source of dissolved organic carbon is terrigenous in the estuarine waters of study area. The general pattern of flocculation of studied metals is manganese $(180 \mu \mathrm{g} / \mathrm{L})>$ zinc $(88 \mu \mathrm{g} / \mathrm{L})>$ nickle $(73 \mu \mathrm{g} / \mathrm{L})>$ copper $(30$ $\mu \mathrm{g} / \mathrm{L})>$ lead $(19 \mu \mathrm{g} / \mathrm{L})$. The results of present study show that metal species are a very important factor in overall flocculation rate. It is found that solids and oxides have the highest and lowest flocculation levels, respectively. Eh-pH diagram indicated that lead is present as lead oxide in Minab River water and the least flocculation rate is attributed to this element. The results also showed that flocculation rate of metal species could be as solids $>$ free ions $\approx$ hydroxides $>$ oxides. The amount of metal flocculation is about 30.5, 6.6, 25.3, 10.4 and 62.5 ton/y for zinc, $\mathrm{Pb}, \mathrm{Ni}, \mathrm{Cu}$ and $\mathrm{Mn}$, respectively.
\end{abstract}

Keywords: Environment; Estuary; Flocculation; Metal; Pollution; River; Species; Water

\section{INTRODUCTION}

Fluxes of materials (dissolved and particulate matters) find their way into lakes and seas through rivers (Meybeck, 1988). Estuaries are the major biogeochemical interfaces between land and sea where terrigenous elements born by river on their way to the sea under go various changes (Sharp et al., 1982; Breuer et al., 1999). Mixing of river and seawater results in flocculation of trace metals especially in the upper part of the estuary where lower salinity regimes are found (Gerringa et al., 2001; Karbassi et al., 2008a; Biati et al., 2010). Due to the flocculation process a large portion of the dissolved metals supplied by the river come into particulate phase (Eckert and Sholkvitz, 1976; Boyle, 1977; Sholkovitz et al., 1977; Karbassi et al., 2008b; c). Thus, estuarine processes can influence elemental composition of the sea water (Sillen, 1961; Mackenzie and Garrels, 1966; Mackenzie, 1975; Troup and Bricker, 1975; Nouri et al., 2008a). The two important mechanisms affecting the concentration and distribution of trace metals during estuarine mixing have been successfully modeled by water-column mixing experiments (Sholkovitz, 1976; Comans and Van Dijk,

凶*Corresponding Author Email: bayati_id@yahoo.com Tel./Fax: +989123777164
1988; Samarghandi et al., 2007). These two counteractive, non biological mechanisms are desorption of metals from resuspension of riverine particles and flocculation of metals-humate from solution (Li et al., 1984). Controlling mechanisms of flocculation process have been investigated intensively. In wetlands, flocculation is enhanced by increased $\mathrm{pH}$, turbulence, concentration of suspended matters, ionic strength and high algal concentration (Matagi et al., 1998; Zvinowanda et al., 2009). Flocculation mechanisms are mainly due to colloidal stability, surface properties, humic acids, salinity and pH (Hunter, 1983; Zhiging, et al., 1987; Featherstone and O’Grady, 1997; Karbassi et al., 2007). Removal of significant amounts of reiverine dissolved organic carbon (DOC) may occur due to flocculation or precipitation reactions that result in the conversion of DOC to particulate organic carbon and their subsequent settlement on to the sediments (Sholkovitz, 1976; Nouri et al., 2008b). Production of autochthonous DOC in estuaries may also occur through several processes (Sharp, 1991; Aliabadi et al., 2006). Although many studies have reported conservative mixing of DOC during estuarine transport (Moor et al., 1979; 
Laane, 1980; Sharp et al., 1982; Mantoura and Woodward, 1983; Aminot et al., 1990), some investigations displayed a relatively dynamic DOC pool (Doering et al., 1994). Redox processes is of major concern for mobilization of trace metals in estuaries where an oxygen gradient exists in addition to the salinity gradient (Gerringa et al., 2001; Abdel-Ghani et al., 2009). A combination of high organic matter content and a long residence time, may result in development of anoxic conditions that may be either restricted to the sediments (Westerlund et al., 1986; Kerner and Wallmann 1992) or can occur in the water column (Zwolsman and Van Eck, 1993; Zwolsman et al., 1997; Shiller and Mao, 1999). Sulfides of elements (e.g. zinc (Zn) and cadmium (Cd)) may precipitate in anoxic conditions (Malakootian et al., 2009). In more saline parts of the estuary, some elements (e.g. $\mathrm{Zn}$ and $\mathrm{Cd}$ ) are released in to the water as a result of oxidation (Sholkovitz, 1976; Duinker and Nolting, 1978; Duinker et al., 1983; Wollast, 1988; Regnier and Wollast, 1993; Chiffoleau et al., 1994; Paucot and Wollast, 1997). Flocculation process has been studied in northern part of Iran (Haraz, Sefidrud, Chalus, Talar, Tadjan and Gorgan rud rivers) (Karbassi and Nadjafpour, 1996; Karbassi et al., 2007, 2008a). Such investigations has not been carried out in southern part of Iran. Present study would fill up such gap for southern coasts of Iran.

\section{MATERIALS AND METHODS}

Strait of Hormuz is an important corridor that connects Iran and other oil producing economic countries (OPEC) to the world's open seas. Strait of Hormuz has a width of 50 to $60 \mathrm{Km}$. Maximum depth of water in strait of Hormuz is $100 \mathrm{~m}$. Minab Rive has a length of $200 \mathrm{Km}$ and its average annual discharge is $10.99 \mathrm{~m}^{3} / \mathrm{s}$. Minab River is formed by two main branches named Rudan in western part and Jaghin in eastern part. It lies between longitude of $57^{\circ} 07^{\prime}$ and Latitude of $27^{\circ} 09^{\prime}$. Various municipal and industrial waste water containing heavy metals and organics along with agricultural fertilizers, pesticides and herbicides enter into the Minab River. Fresh and saline water samples were collected in pre-cleaned $25 \mathrm{~L}$ polyethylene bucket from the Minab River upstream and Strait of Hormuz (16 Km away from river mouth), respectively (Fig. 1). Water sampling was carried out on $5^{\text {th. }}$ October 2008. On the same day, water samples were filtered through $0.45 \mu \mathrm{m}$ Millipore AP and HA filters. About one liter of filtered fresh water was acidified with concentrated $\mathrm{HNO}_{3}$ to a pH of approximately 1.8 and stored in polyethylene bottles in a refrigerator prior to analysis of dissolved metals. Filtered river water and seawater were mixed together at room temperature (ca. $25^{\circ} \mathrm{C}$ ) in nine proportions yielding salinities of 3.3-29.7. The

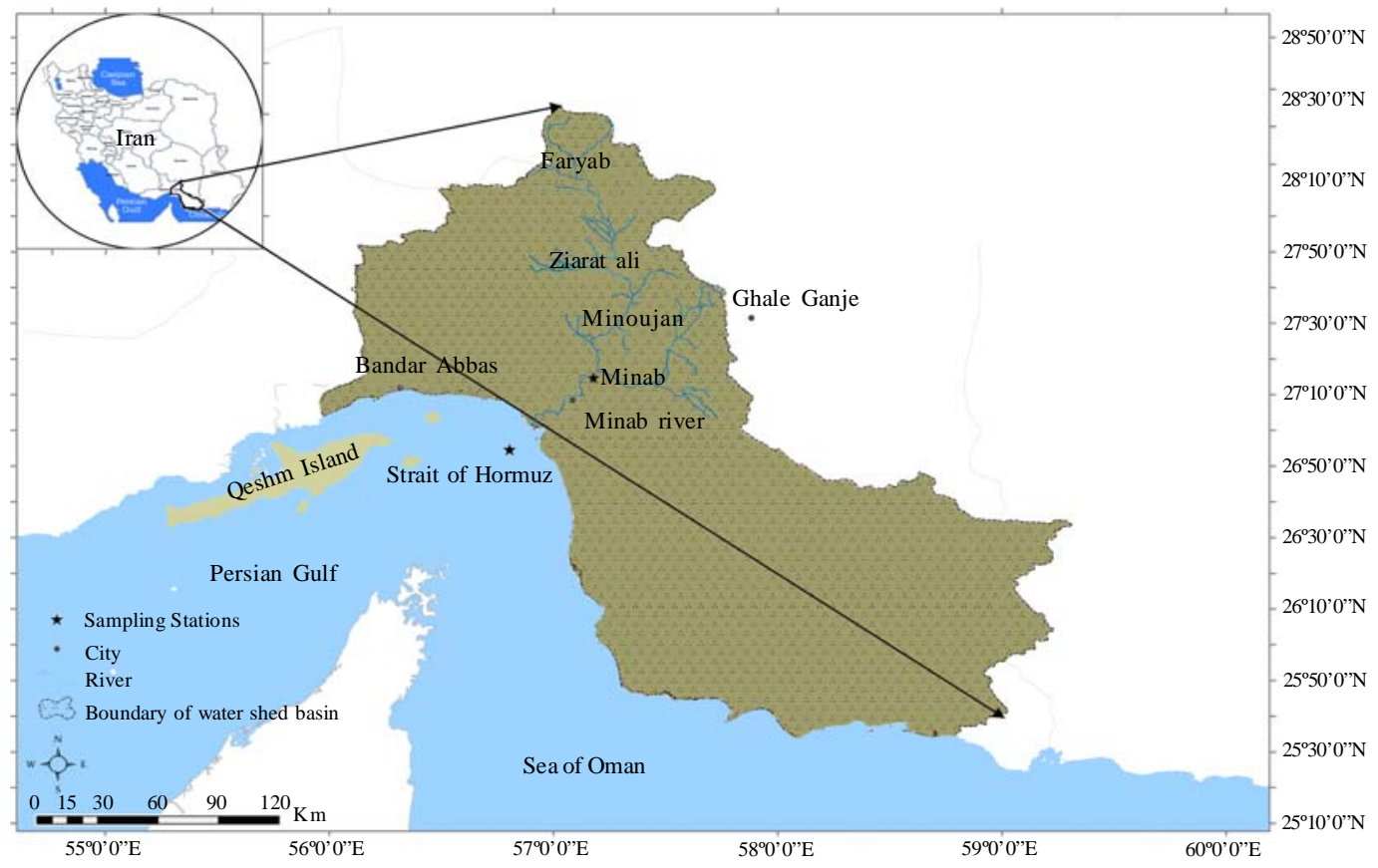

Fig. 1: Locations of water samples from Minab River and Strait of Hormuz 
Int. J. Environ. Sci. Tech., 7 (2), 327-336, Spring 2010

Table 1: Methods and apparatus used for measurement of various parameters

\begin{tabular}{|c|c|}
\hline Parameter & Method/ apparatus of measurement \\
\hline $\mathrm{Mn}, \mathrm{Cu}, \mathrm{Pb}, \mathrm{Zn}, \mathrm{Ni}$ & ICP (JOBINYVON model JY138 ULTARCE \\
\hline $\mathrm{Ca}, \mathrm{Mg}$ & AAS (Varian, model Spectraa. 200) \\
\hline $\mathrm{Na}$ & Flame photometer \\
\hline $\mathrm{pH} / \mathrm{Eh}$ & pH meter (Metrohm 744) \\
\hline EC & Conductimeter (CRISON GLP32) \\
\hline DO & DO meter (Inolab WTW) \\
\hline DOC & Photo cathalitical oxidation method (ANATOC ${ }^{\mathrm{TM}}$ SERIES II) \\
\hline Chloride & Argentometric method (4500- $\left.\mathrm{Cl}^{-}\right) \quad$ (APHA, 2005) \\
\hline Sulfate & Turbidimetric method $\left(4500-\mathrm{SO}_{4}^{-2}\right)$ \\
\hline Alkalinity of phenol and methyl & Titration method (2320) \\
\hline Salinity, carbonate, bicarbonate, total alkalinity & Titration method \\
\hline Temp. of water & Thermometer (accuracy of $1 \mathrm{C}^{\circ}$ ) \\
\hline
\end{tabular}

Table 2: Flocculants of trace metal contents (laboratory scale) along with pH, Eh, EC, temperature, salinity, DO and DOC laboratory condition

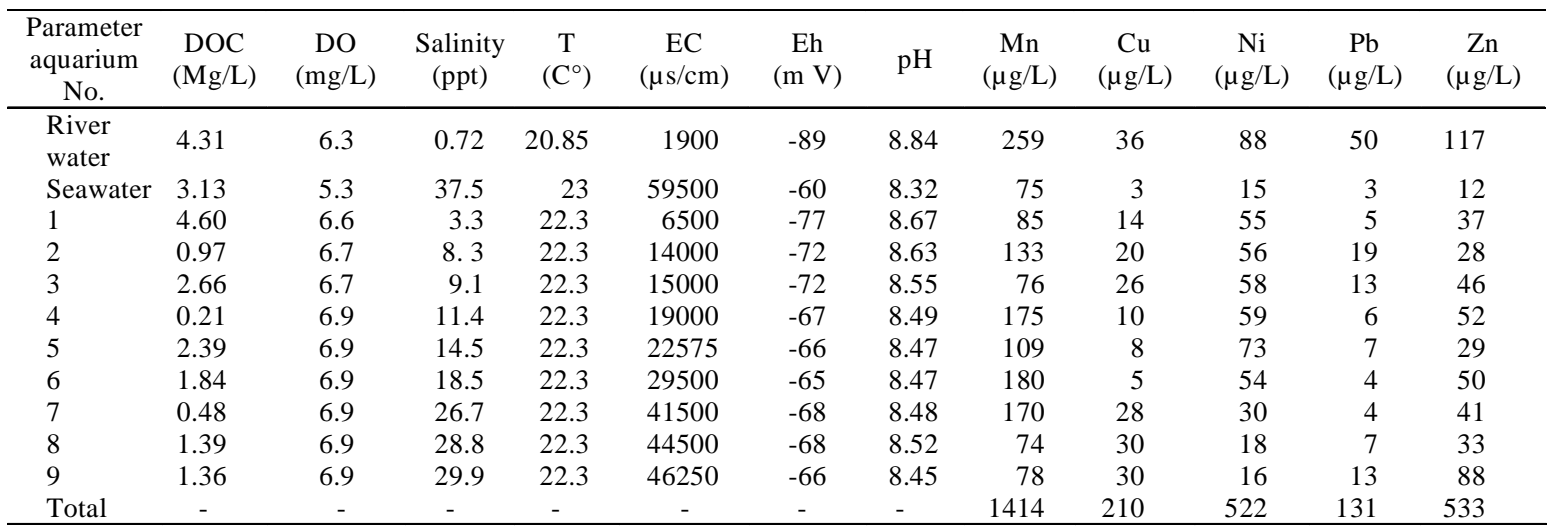

samples were kept for $24 \mathrm{~h}$ with occasional stirring. The resulting flocculants were collected on $47 \mathrm{~mm}$ diameter Millipore membrane filters (type HA, Pore size $0.45 \mu \mathrm{m}$ ) Millipore filters were digested using $5 \mathrm{ml}$ concentrated $\mathrm{HNO}_{3}$ overnight. The concentrations of copper $(\mathrm{Cu})$, zinc $(\mathrm{Zn})$, nickel $(\mathrm{Ni})$, lead $(\mathrm{Pb})$ and manganese (Mn) were determined by ICP (JOBINYVON model JY 138 ULTRACE). Procedural blanks and duplicates were run with the samples in a similar way. Table 1 shows summary of methods used in the present investigation.

\section{RESULTS AND DISCUSSION}

The metal contents of flocculants along with $\mathrm{pH}$, Eh, EC, temperature, salinity, DO and DOC are shown in Table 2. It should be pointed out that data on trace metal contents are not the real ones since flocculation processes carried out in laboratory scale does not occur in nature. In other words, at laboratory scale fresh water with its initial trace metal contents is mixed up with saline water. But, in the nature fresh water does not mixes up with saline water in the way it is mixed up. For instance, during the very first collision of fresh water with saline water, some trace metals ooze out of fresh water. Subsequently, in the next movement of fresh water towards sea, the river water will not possess its initial metal contents. Therefore, cumulative summation is used to convert the trace metal values obtained in Table 2 and the actual metal contents that occur in nature are presented in Table 3. Thus, the data in Table 2 will not be discussed further.

About $75 \%$ of total $\mathrm{Zn}$ contents $(117 \mu \mathrm{g} / \mathrm{L})$ flocculates during estuarine mixing. The highest flocculation of $\mathrm{Zn}$ (37 and $36 \mu \mathrm{g} / \mathrm{L}$ ) is found at salinities of 3.3 and 29.9, respectively. The other salinities do not play an important role in the flocculation of $\mathrm{Zn}$. It should be noted that amongst studied metals only $\mathrm{Zn}$ flocculates at salinity of 29.9. The initial concentration of $\mathrm{Pb}$ in Minab Rive water is $50 \mu \mathrm{g} / \mathrm{L}$ and only $19 \mu \mathrm{g} / \mathrm{L}$ of $\mathrm{Pb}$ flocculates during estuarine mixing (about $38 \%$ of total $\mathrm{Pb}$ content). The flocculation of $\mathrm{Pb}$ is rather unique amongst studied metals ( $\mathrm{Zn}, \mathrm{Ni}, \mathrm{Cu}$ and $\mathrm{Mn}$ ) since its flocculation occurs at salinities of 3.3 and 8.3. The majority of Ni flocculation (about $55 \mu \mathrm{g} / \mathrm{L}$ ) occurs 
Estuarine metal speciations

Table 3: Flocculants of trace metal contents (natural scale) along with pH, Eh, EC, temperature, salinity, DO and DOC - Natural condition

\begin{tabular}{|c|c|c|c|c|c|c|c|c|c|c|c|c|}
\hline $\begin{array}{c}\text { Parameter } \\
\text { Aquarium No. }\end{array}$ & $\begin{array}{c}\text { DOC } \\
(\mathrm{Mg} / \mathrm{L})\end{array}$ & $\begin{array}{c}\mathrm{DO} \\
(\mathrm{mg} / \mathrm{L})\end{array}$ & $\begin{array}{l}\text { Salinity } \\
\text { (ppt) }\end{array}$ & $\begin{array}{c}\mathrm{T} \\
\left({ }^{\circ} \mathrm{C}\right)\end{array}$ & $\begin{array}{c}\mathrm{EC} \\
(\mu \mathrm{s} / \mathrm{cm})\end{array}$ & $\begin{array}{c}\text { Eh } \\
(\mathrm{mV})\end{array}$ & $\mathrm{pH}$ & $\begin{array}{c}\text { Mn } \\
(\mu g / L)\end{array}$ & $\begin{array}{c}\mathrm{Cu} \\
(\mu \mathrm{g} / \mathrm{L})\end{array}$ & $\begin{array}{c}\mathrm{Ni} \\
(\mu \mathrm{g} / \mathrm{L})\end{array}$ & $\begin{array}{c}\mathrm{Pb} \\
(\mu \mathrm{g} / \mathrm{L})\end{array}$ & $\begin{array}{c}\mathrm{Zn} \\
(\mu \mathrm{g} / \mathrm{L})\end{array}$ \\
\hline River water & 4.31 & 6.3 & 0.72 & 20.85 & 1900 & -89 & 8.84 & 259 & 36 & 88 & 50 & 117 \\
\hline Seawater & 3.13 & 5.3 & 37.5 & 23 & 59500 & -60 & 8.32 & 75 & 3 & 15 & 3 & 12 \\
\hline 1 & 4.60 & 6.6 & 3.3 & 22.3 & 6500 & -77 & 8.67 & $\begin{array}{r}85 \\
(32.8)\end{array}$ & $\begin{array}{r}14 \\
(38.9)\end{array}$ & $\begin{array}{r}55 \\
(62.5)\end{array}$ & $\begin{array}{r}5 \\
(10)\end{array}$ & $\begin{array}{r}37 \\
(31.6)\end{array}$ \\
\hline 2 & 0.97 & 6.7 & 8. 3 & 22.3 & 14000 & -72 & 8.63 & $\begin{array}{r}48 \\
(18.5)\end{array}$ & $\begin{array}{r}6 \\
(16.7)\end{array}$ & $\begin{array}{r}1 \\
(1.1)\end{array}$ & $\begin{array}{r}14 \\
\text { (28) }\end{array}$ & $\begin{array}{r}0 \\
(0)\end{array}$ \\
\hline 3 & 2.66 & 6.7 & 9.1 & 22.3 & 15000 & -72 & 8.55 & $\begin{array}{r}0 \\
(0)\end{array}$ & $\begin{array}{r}6 \\
(16.7)\end{array}$ & $\begin{array}{r}2 \\
(2.3)\end{array}$ & $\begin{array}{r}0 \\
(0)\end{array}$ & $\begin{array}{r}9 \\
(7.7)\end{array}$ \\
\hline 4 & 0.21 & 6.9 & 11.4 & 22.3 & 19000 & -67 & 8.49 & $\begin{array}{r}42 \\
(16.2)\end{array}$ & $\begin{array}{r}0 \\
(0)\end{array}$ & $\begin{array}{r}1 \\
(1.1)\end{array}$ & $\begin{array}{r}0 \\
(0)\end{array}$ & $\begin{array}{r}6 \\
(5.1)\end{array}$ \\
\hline 5 & 2.39 & 6.9 & 14.5 & 22.3 & 22575 & -66 & 8.47 & $\begin{array}{r}0 \\
(0)\end{array}$ & $\begin{array}{r}0 \\
(0)\end{array}$ & $\begin{array}{r}14 \\
(15.9)\end{array}$ & $\begin{array}{r}0 \\
(0)\end{array}$ & $\begin{array}{r}0 \\
(0)\end{array}$ \\
\hline 6 & 1.84 & 6.9 & 18.5 & 22.3 & 29500 & -65 & 8.47 & $\begin{array}{r}5 \\
(1.9)\end{array}$ & $\begin{array}{r}0 \\
(0)\end{array}$ & $\begin{array}{r}0 \\
(0)\end{array}$ & $\begin{array}{r}0 \\
(0)\end{array}$ & $\begin{array}{r}0 \\
(0)\end{array}$ \\
\hline 7 & 0.48 & 6.9 & 26.7 & 22.3 & 41500 & -68 & 8.48 & $\begin{array}{r}0 \\
(0)\end{array}$ & $\begin{array}{r}2 \\
(5.5)\end{array}$ & $\begin{array}{r}0 \\
(0)\end{array}$ & $\begin{array}{r}0 \\
(0)\end{array}$ & $\begin{array}{r}0 \\
(0)\end{array}$ \\
\hline 8 & 1.39 & 6.9 & 28.8 & 22.3 & 44500 & -68 & 8.52 & $\begin{array}{r}0 \\
(0)\end{array}$ & $\begin{array}{r}2 \\
(5.5)\end{array}$ & $\begin{array}{r}0 \\
(0)\end{array}$ & $\begin{array}{r}0 \\
(0)\end{array}$ & $\begin{array}{r}0 \\
(0)\end{array}$ \\
\hline 9 & 1.36 & 6.9 & 29.9 & 22.3 & 46250 & -66 & 8.45 & $\begin{array}{r}0 \\
(0)\end{array}$ & $\begin{array}{r}0 \\
(0)\end{array}$ & $\begin{array}{r}0 \\
(0)\end{array}$ & $\begin{array}{r}0 \\
(0)\end{array}$ & $\begin{array}{r}36 \\
(30.80)\end{array}$ \\
\hline Total & - & - & - & - & - & - & - & $\begin{array}{r}180 \\
(69.4)\end{array}$ & $\begin{array}{r}30 \\
(83.3)\end{array}$ & $\begin{array}{r}73 \\
(82.9) \\
\end{array}$ & $\begin{array}{r}19 \\
(38)\end{array}$ & $\begin{array}{r}88 \\
(75.2) \\
\end{array}$ \\
\hline
\end{tabular}

Table 4: Concentrations of anions and cations in river and Gulf waters along with aquariums

\begin{tabular}{|c|c|c|c|c|c|c|c|c|}
\hline $\begin{array}{c}\text { Parameter } \\
\text { aquarium No. }\end{array}$ & $\begin{array}{c}\mathrm{SO}_{4} \\
(\mathrm{mg} / \mathrm{L})\end{array}$ & $\begin{array}{c}\mathrm{HCO}_{3} \\
(\mathrm{mg} / \mathrm{L})\end{array}$ & $\begin{array}{c}\mathrm{CO}_{3} \\
(\mathrm{mg} / \mathrm{L})\end{array}$ & $\begin{array}{l}\text { Total alkalinity } \\
\left(\mathrm{mg} \mathrm{CaCO}_{3} / \mathrm{L}\right)\end{array}$ & $\begin{array}{c}\mathrm{Cl} \\
(\mathrm{mg} / \mathrm{L})\end{array}$ & $\begin{array}{c}\mathrm{Ca} \\
(\mathrm{mg} / \mathrm{L})\end{array}$ & $\begin{array}{c}\mathrm{Mg} \\
(\mathrm{mg} / \mathrm{L})\end{array}$ & $\begin{array}{c}\mathrm{Na} \\
(\mathrm{mg} / \mathrm{L})\end{array}$ \\
\hline Seawater & 1920.8 & 13.42 & 4.8 & 27 & 22727.27 & 4161 & 1288.8 & 9550 \\
\hline 2 & 1070.16 & 35.38 & 12 & 49 & 5000 & 282.8 & 300 & 2800 \\
\hline 3 & 1100 & 34.16 & 9.6 & 44 & 5500 & 276.1 & 440.3 & 3200 \\
\hline 4 & 1350 & 32.94 & 9.6 & 43 & 6900 & 389.9 & 623.6 & 3900 \\
\hline 7 & 2003.12 & 29.28 & 7.2 & 36 & 16181.82 & 476 & 800.9 & 8325 \\
\hline 8 & 1920.8 & 18.30 & 6.0 & 25 & 17454.54 & 425 & 806.2 & 9250 \\
\hline 9 & 1975.68 & 24.4 & 7.2 & 32 & 18125 & 471 & 1021.4 & 9360 \\
\hline
\end{tabular}

at 3.3 salinity. Flocculation of Ni ranges from 1 to 2 $\mu \mathrm{g} / \mathrm{L}$ at salinities of 8.3 to 11.4 and again raises to 14 $\mu \mathrm{g} / \mathrm{L}$ at salinity of 14.5 . Nickle does not flocculates at salinities higher than 14.5 . In general, about $83 \%$ of total $\mathrm{Ni}$ content $(88 \mu \mathrm{g} / \mathrm{L})$ flocculates during estuarine mixing. The over all flocculation of $\mathrm{Cu}$ resembles $\mathrm{Ni}$ and $83 \%$ of its initial content (36 $\mu \mathrm{g} / \mathrm{L})$ flocculates during estuarine mixing. The higher flocculation rate for $\mathrm{Cu}$ occurs at salinity of 3.3 its flocculation can be traced at other salinities (8.3 and 9.1) and to a lower extent at 26.7 and 28.8, as well. Highest flocculation of Mn (about $33 \mu \mathrm{g} / \mathrm{L}$ ) occurs at 3.3. However, Mn flocculates at salinities of 8.3 and 11.4. In general, about $70 \%$ of initial content of riverine Mn (259 $\mu \mathrm{g} / \mathrm{L})$ flocculates during estuarine mixing. The general pattern of flocculation of studied metals is Mn $(180 \mu \mathrm{g} / \mathrm{L})>\mathrm{Zn}$ $(88 \mu \mathrm{g} / \mathrm{L})>\mathrm{Ni}(73 \mu \mathrm{g} / \mathrm{L})>\mathrm{Cu}(30 \mu \mathrm{g} / \mathrm{L})>\mathrm{Pb}(19 \mu \mathrm{g} / \mathrm{L})$. However, the percentages of flocculation taking into consideration the initial metal contents in river water is $\mathrm{Cu}(83.3 \%)>\mathrm{Ni}(82.9 \%)>\mathrm{Zn}(75.5 \%)>\mathrm{Mn}(69.4 \%)$ $>\mathrm{Pb}$ (38\%). Except for $\mathrm{Zn}$, other studied metals flocculates at higher rates when compared with metal contents of rivers flowing into the Caspian sea in the northern part of Iran (Karbassi et al., 2007; 2008). It should be pointed out that the initial metal contents of rivers flowing into the Caspian Sea are lower than Minab River that discharges into the Strait of Hormuz. Therefore, it can be inferred that higher initial metal contents in river water will result in higher metal flocculation in estuaries. As Karbassi et al. (2007; 2008) 
stated, salinity is a general term that does not necessarily show the effect of other saline water constituents on the flocculation of metals in the estuarine zone. Therefore, other parameters such as pH, DO, EC, $\mathrm{Eh}, \mathrm{Ca}, \mathrm{DOC}, \mathrm{SO}_{4}, \mathrm{Mg}, \mathrm{Na}, \mathrm{K}, \mathrm{CO}_{3}, \mathrm{HCO}_{3}$ and Alkalinity were measured (Table 4) in freshwater, seawater and the nine aquariums. Fig. 2 is indicative of a rather good balance among studied anions and caution. However, Fig. 3 shows that a considerable portion of river water falls in $\mathrm{SO}_{4}, \mathrm{Cl}^{-}$and $\mathrm{Na}+\mathrm{K}$ classification that is not indicative of suitable potable water. This is more clear in Fig. 4 where piper diagram is used for the classification of Minab River water. Wilcox diagram also classifies the Minab River water as $\mathrm{C}_{3} \mathrm{~S}_{2}$ class that is indicative of high salinity hazard (Fig. 5). The Eh-pH diagrams (Fig. 6) show that Ni and Mn could be present as free ions while $\mathrm{Pb}$ could be present as $\mathrm{PbO}$ in riverine waters. On the other hand, speciation of $\mathrm{Zn}$ and $\mathrm{Cu}$ falls within $\mathrm{ZnOH}$ and $\mathrm{Cu}(\mathrm{s})$ classes, respectively. This may to some extend justify the reason for changes in the rates of flocculation of studied metals. For example, $\mathrm{Pb}$ that is less flocculated during estuarine mixing is present as $\mathrm{PbO}$ in Minab River water. On the other hand, $\mathrm{Cu}$ that is found as $\mathrm{Cu}(\mathrm{s})$ shows highest rate of flocculation

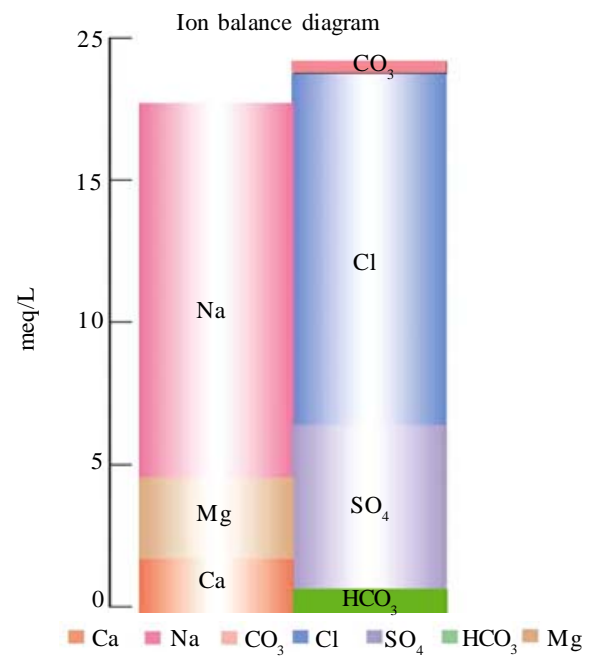

Fig. 2: Diagram of ion balance for Minab river water

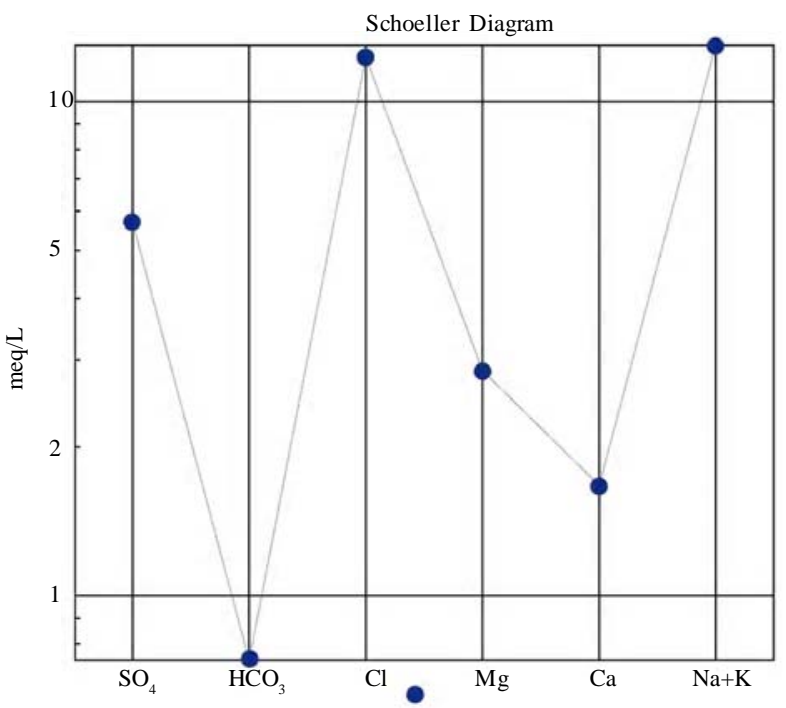

Fig. 3: Schoeller diagram for Minab River water 


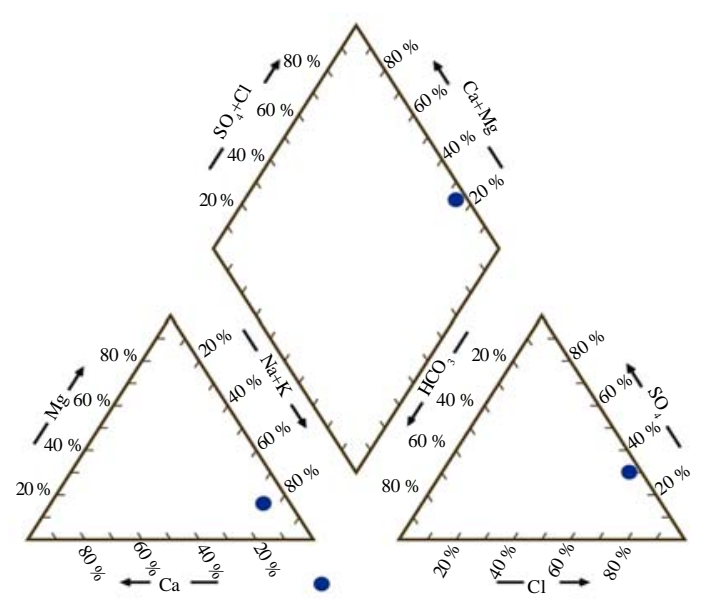

Fig. 4: Piper diagram for Minab River water

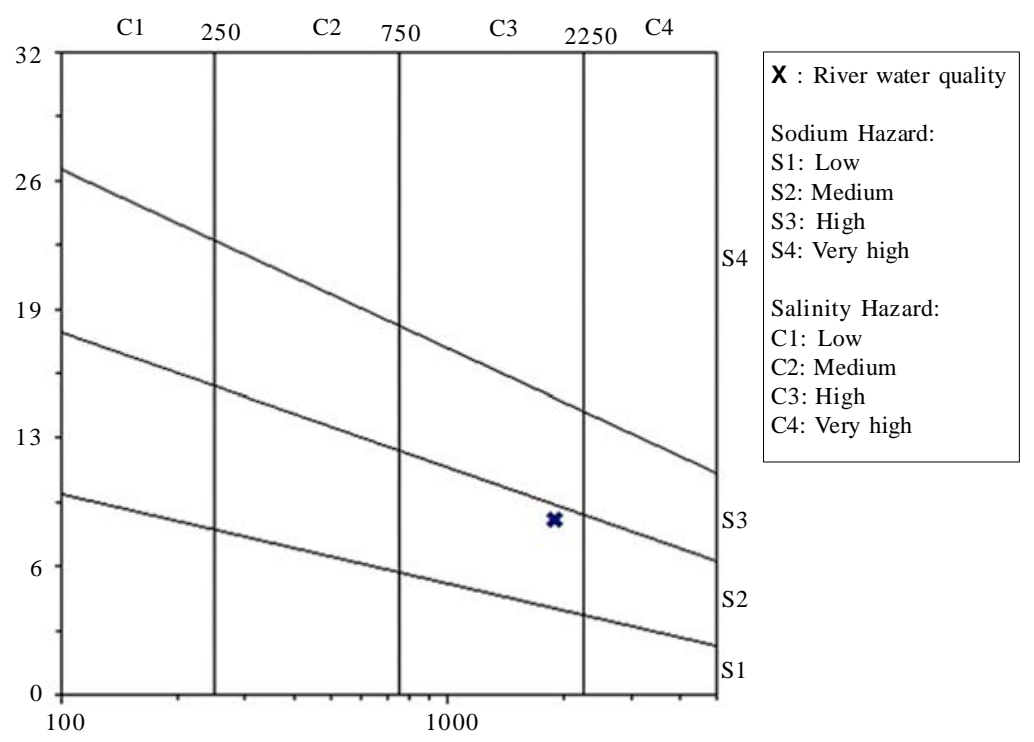

Fig. 5: Wilcox diagram for Minab River water

during estuarine mixing. Free ions such as $\mathrm{Ni}$ and $\mathrm{Mn}$ and also $\mathrm{Zn}$ which could be present as $\mathrm{ZnOH}$ have flocculation range closer to solids $\mathrm{Cu}(\mathrm{s})$ than oxides $(\mathrm{PbO})$. Therefore, one may suggest the following pattern for the flocculation of metals during estuarine mixing.

$$
\text { solids }>\text { free ions » hydroxides }>\text { oxides }
$$

Finally, considering the concentrations of dissolved metals in Minab Rive water [Zn (117 $\mu \mathrm{g} / \mathrm{L}), \mathrm{Pb}(50$ $\mu \mathrm{g} / \mathrm{L}), \mathrm{Ni}(88 \mu \mathrm{g} / \mathrm{L}), \mathrm{Cu}(36 \mu \mathrm{g} / \mathrm{L})$ and Mn $(259 \mu \mathrm{g} / \mathrm{L})]$ and the mean discharge of river $\left(347 \times 10^{6} \mathrm{~m}^{3} / \mathrm{y}\right)$, the annual discharge of dissolved $\mathrm{Zn}, \mathrm{Pb}, \mathrm{Ni}, \mathrm{Cu}$ and $\mathrm{Mn}$ into the Strait of Hormuz via Minab River would be 40.6, 17.4, 30.5, 12.5 and 89.9 ton/y, respectively. However, results of present study show 75.2, 38, 82.9, 83.3 and $69.4 \%$ of dissolved concentrations for $\mathrm{Zn}$, $\mathrm{Pb}, \mathrm{Ni}, \mathrm{Cu}$ and $\mathrm{Mn}$, respectively, flocculates during estuarine mixing. Therefore, the mean annual discharge of dissolved $\mathrm{Zn}, \mathrm{Pb}, \mathrm{Ni}, \mathrm{Cu}$ and $\mathrm{Mn}$ from Minab River into Strait of Hormuz would reduce from 40.6, 17.4, $30.5,12.5$ and 89.9 ton/y to 10.1, 10.8, 5.2, 2.1 and 27.5 ton/y, respectively. Further cluster analysis was carried out to evaluate the intera-relationship amongst metal flocculation and governing factors. Many studies show that salinity and $\mathrm{pH}$ are the main governing 

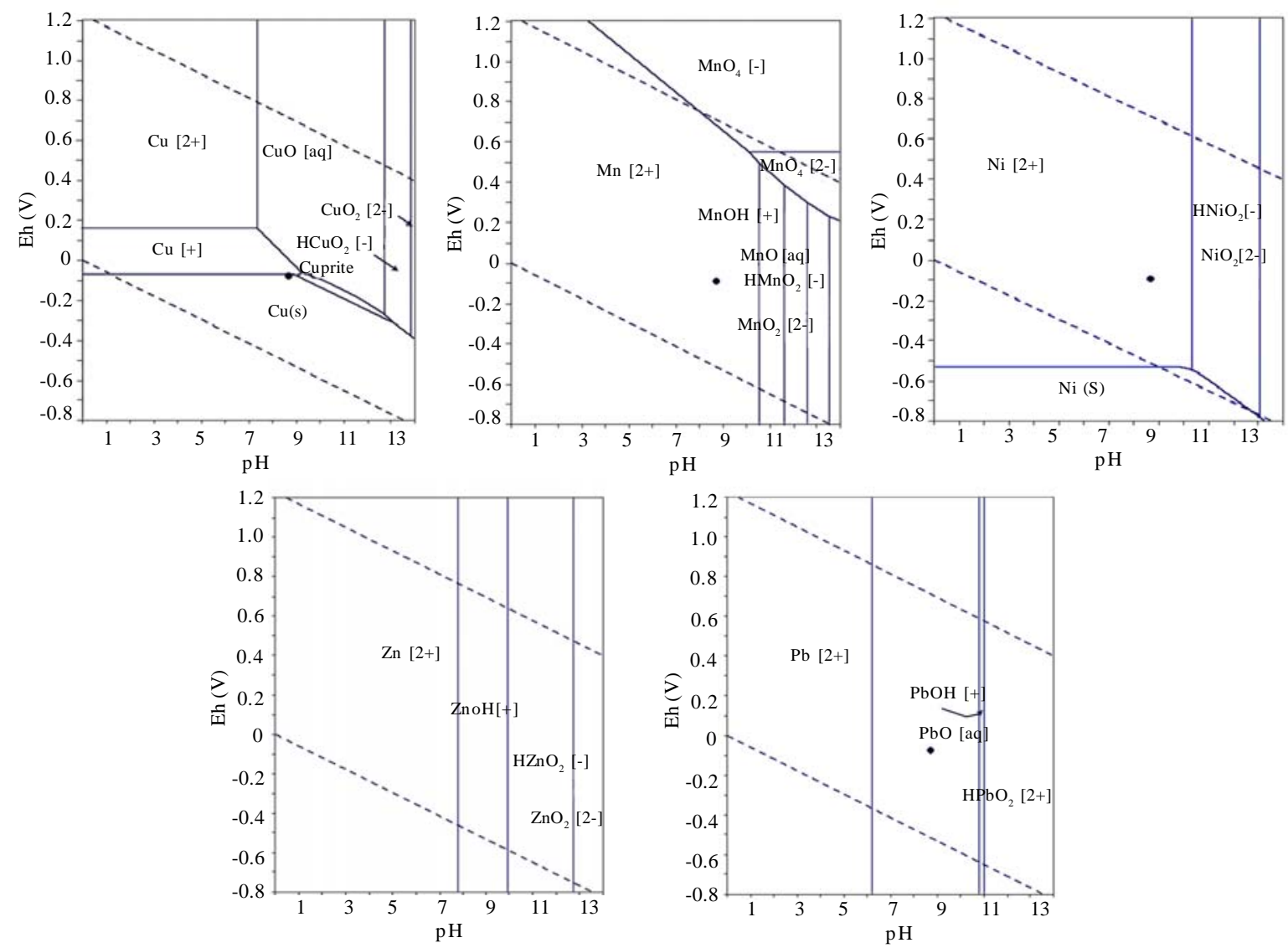

Fig. 6: Eh- $\mathrm{pH}$ diagram of $\mathrm{Ni}, \mathrm{Mn}, \mathrm{Cu}, \mathrm{Zn}$ and $\mathrm{Pb}$ in Minab River water

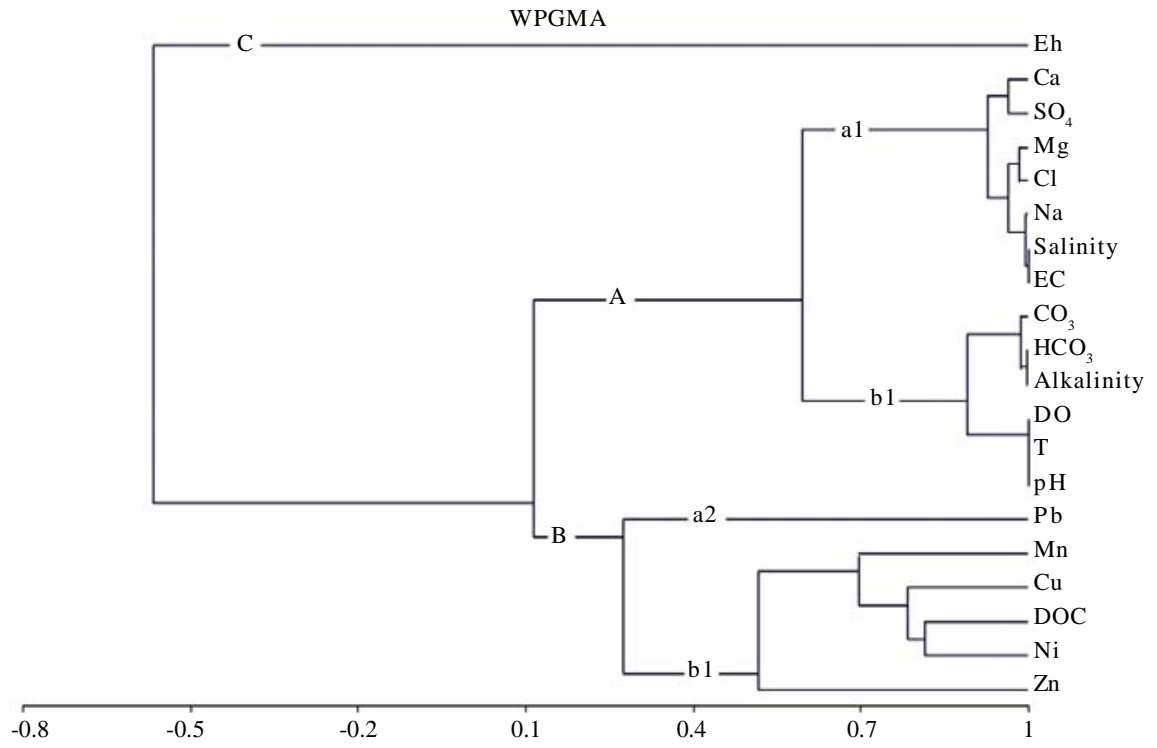

Fig. 7: Dendrogram of cluster analysis amongst studied parameter in Minab Estuarine zone 
factors in the flocculation of metals during estuarine mixing (Boyle et al., 1977; Duinker et al., 1983; Hunter 1983; Zhiqing et al., 1987). However, cluster analysis (Fig. 7) shows that DOC is the main governing factor for the flocculation of $\mathrm{Zn}, \mathrm{Ni}, \mathrm{Cu}$ and $\mathrm{Mn}$ in the Minab estuary. This finding is in agreement with the studies of Sholkovitz (1976), Mantoura and Woodward (1983), Meyer (1983).

It seems that DOC has a little effect on the flocculation of $\mathrm{Pb}$. Further investigations are required to find out governing factors for the flocculation of $\mathrm{Pb}$ during estuarine mixing.

Van der Berg et al., (1987) have clearly showed the effect of dissolved organic complexing ligand on the geochemical cycle of $\mathrm{Zn}$ and $\mathrm{Cu}$ in Scheldt estuary. They argue that $\mathrm{Zn}$ and $\mathrm{Cu}$ contents are regulated by DOC. Kozelka and Bruland (1998) showed that organic chelates of $\mathrm{Cu}, \mathrm{Zn}, \mathrm{Pb}$ and $\mathrm{Cd}$ are the dominant forms in Narragansett Bay. Zwolsman et al., (1997) showed rapid removal of $\mathrm{Cu}, \mathrm{Zn}$ and $\mathrm{Cd}$ in the very low salinity zone of Scheldt estuary. They argued that flocculation due to formation of organo-metal complexes along with coagulation of colloids and also formation of $\mathrm{Fe}$ and Mn hydroxide could likely be involved in removal processes.

Cluster analysis shows that $\mathrm{pH}$, temperature, DO, alkalinity, $\mathrm{HCO}_{3}, \mathrm{CO}_{3}$, EC, salinity, $\mathrm{Na}, \mathrm{Cl}, \mathrm{Mg}, \mathrm{SO}_{4}, \mathrm{Ca}$ and Eh do not have any effect on the flocculation processes during mixing of the Minab River water with the Strait of Hormuz waters during estuarine mixing. Though, DOC shows high similarity coefficients with $\mathrm{Cu}, \mathrm{Zn}, \mathrm{Ni}$ and $\mathrm{Mn}$ but its concentration is very low in the Minab River water $(4.3 \mathrm{mg} / \mathrm{L})$ and also the Strait of Hormuz waters $(3.1 \mathrm{mg} / \mathrm{L})$. Though some studies on Iranian estuaries show that marine carbon source (about $50 \mathrm{mg} / \mathrm{L}$ ) dominates over riverine (2 mg/L) DOC (Karbassi et al., 2008b), but such difference is not seen for the study area. The DOC content of Minab River $(4.3 \mathrm{mg} / \mathrm{L})$ is slightly higher than Strait of Hormuz's water $(3.1 \mathrm{mg} / \mathrm{L})$. Though DOC content increases (4.6 $\mathrm{mg} / \mathrm{L})$ in the initial stages of mixing freshwater with saline water (3.3), but it decreases at other salinities (8.3 to 29.9). The lowest DOC $(0.21 \mathrm{mg} / \mathrm{L})$ is found at salinity of 11.4. Conservative DOC behavior is reported during estuarine mixing in Beaulieu Estuary, England (Moore et al., 1979). In the area of investigation, DOC behavior is non-linear and non-conservative. Karbassi et al. (2008a) reported linear DOC increase for the rivers flowing into the Caspian Sea. Mantoura and Mann
(1979) reported linear decrease in DOC over salinity range from 17 to 28 for Bristol Channel. In short, it might be inferred that DOC originates from terrigenous source in the study area.

\section{CONCLUSION}

The flocculation rate of $\mathrm{Zn}, \mathrm{Pb}, \mathrm{Cu}, \mathrm{Ni}$ and $\mathrm{Mn}$ during estuarine mixing of Minab River with the Strait of Hormuz water were investigated. The results showed that studied metals flocculates at different salinities; however, except for $\mathrm{Zn}$, the most important salinity regime varies between 3.3 to 11.4. Among common parameters (salinity, EC, pH, DO, temperature and DOC) that are known as governing flocculation factors only DOC play major role in flocculation of metals (except for $\mathrm{Pb}$ ) during estuarine mixing in the study area. The source of DOC is terrigenous and the Strait of Hormuz waters do not contribute to DOC contents of Minab River estuarine zone. Eh-pH diagram indicated that $\mathrm{Pb}$ is present as $\mathrm{PbO}$ in Minab River water and the least flocculation rate is attributed to this element. The results also showed that flocculation rate of metal species could be as solids $>$ free ions $\approx$ hydroxides $>$ oxides. The flocculation rate of studied metals showed that the overall metal pollution load can be reduced by various percentile (ranging from $38 \%$ to $83 \%$ ) during estuarine mixing of Minab river water with the Strait of Hormuz water. Therefore, estuarine processes can be considered as effective mechanism in self purification of colloidal metals that are anthropogenically entered into the fresh water eco-system. It is also concluded that higher initial metal contents in river water can lead to higher metal flocculation during estuarine mixing.

\section{REFERENCES}

Abdel-Ghani, N. T.; Hegazy, A. K.; El-Chaghaby, G. A., (2009). Typha domingensis leaf powder for decontamination of aluminium, iron, zinc and lead: Biosorption kinetics and equilibrium modeling. Int. J. Environ. Sci. Tech., 6 (2), 243248 (6 pages).

Aliabadi, M.; Morshedzadeh, K.; Soheyli, H. R., (2006). Removal of hexavalent chromium from aqueous solution by Lignocellulosic solid wastes. Int. J. Environ. Sci. Tech., 3 (3), 321-325 (5 pages).

Aminot, A. M. A.; EL-Sayed, Kerouel, R., (1990). Fate of Natural and Anthropogenic Dissolved Organic Carbon in the Macrotidal Elorn Estuary (France). Mar. Chem., 29 (C), 255-275 (21 pages).

APHA, (2005). Standard methods for the examination of water and wastewater. American Public Health Association (APHA), $18^{\text {th. }}$ Ed., Washington, DC.

Biati, A.; Moattar, F.; Karbassi, A. R.; Hassani, A. H., (2010). Role of saline water in removal of heavy elements from 
industrial wastewaters. Int. J. Environ. Res., 4 (1), 169-176 (8 pages).

Boyle, E. A.; Edmond, J. M.; Sholkovitz, E. R., (1977). The Mechanism of iron removal in estuaries. Geochim. Cosmochim. Acta, 41 (9), 1313-1324 (12 pages).

Breuer, E.; Sanudo-Wilhelmy, S. A.; Aller, R. C., (1999). Trace metals and dissolved organic carbon in an estuary with restricted river flow and a brown tide bloom. Estuaries, 22 (3A), 603-615 (13 pages).

Chiffoleau, J. F.; Cossa, D.; Auger, D.; Truquet, I., (1994). Trace metal distribution, partition and fluxes in the Seine etuary (France) in low discharge regime. Mar. Chem., 47 (2), 145-158 (14 pages).

Comans, R. N.; Van Dijk, C. P. J., (1988). Role of complexation processes in cadmium mobilization during estuarine mixing. Nature, 336 (6195), 151-154 (4 pages).

Doering, P. H. C. A.; Oviatt Mckenna, J. H.; Reed, L. W., (1994). Mixing behavior of dissolved organic carbon and its potential biological significance in the Pawcatuck river estuary. Estuaries, 17 (3), 521-536 (16 pages).

Duinker, J. C.; Nolting, R. F., (1978). Mixing, removal and mobilization of trace metals in the Rhine estuary. Neth. J. Sea Res., 12, 205-223 (19 pages).

Duinker, J. C.; Nolting, R. F.; Michel, D., (1983). Effects of salinity, $\mathrm{pH}$ and redox conditions on the behavior of $\mathrm{Cd}, \mathrm{Zn}, \mathrm{Ni}$ and $\mathrm{Mn}$ in the Scheldt estuary. Thalassia Jugosl, 18, 191-201.

Eckert, J. M.; Sholkovitz, E. R., (1976). The flocculation of $\mathrm{Fe}, \mathrm{Al}$ and humates from river water by electrolytes. Geochim. Cosmochim. Acta, 40 (7), 847-856 (10 pages).

Featherstone, A. M.; Oågrady, B. V., (1997). Removal of dissolved $\mathrm{Cu}$ and $\mathrm{Fe}$ at the freshwater - seawater interface of an acid mine stream. Mar. Pollut., 34 (5), 332-337 (5 pages).

Gerringa, L. J. A.; de Baar, H. J. W.; Nolthing, R. F.; Paucot, $\mathrm{H}$., (2001). The influence of salinity on the solubility of $\mathrm{Zn}$ and Cd sulfides in the Scheldt estuary. Sea Res., 46 (3-4), 201-211 (11 pages).

Hunter, K. A., (1983). On the estuarine mixing of dissolved substances in relation to colloidal stability and surface properties. Geochim. Cosmochim. Acta, 47 (3), 467-473 (7 pages).

Karbassi, A. R.; Nadjafpour, S., (1996). Flocculation of dissolved $\mathrm{Pb}, \mathrm{Cu}, \mathrm{Zn}$, and $\mathrm{Mn}$ during estuarine mixing of river water with the Caspian Sea. Environ. Pollut., 93 (3), 257-260 (4 pages).

Karbassi, A. R.; Nouri. J.; Ayaz, G. O., (2007). Flocculation of trace metals during mixing of Talar river water with Caspian Seawater. Int. J. Environ. Res., 1 (1), 66-73 (8 pages).

Karbassi, A. R.; Nouri, J.; Mehrdadi, N.; Ayaz, G. O., (2008a). Flocculation of heavy metals during mixing of freshwater with Caspian Sea water. Environ. Geo., 53 (8), 1811-1816 (6 pages).

Karbassi, A. R., Monavari, S. M., Bidhendi, G. R. N., Nouri, J., Nematpour, K., (2008b). Metal pollution assessment of sediment and water in the Shur River. Environ. Monitor. Assess., 147 (1-3), 107-116 (10 pages).

Karbassi, A. R.; Nouri, J.; Nabi Bidhendi, G. R.; Ayaz, G. O., (2008c). Behavior of $\mathrm{Cu}, \mathrm{Zn}, \mathrm{Pb}, \mathrm{Ni}$ and $\mathrm{Mn}$ during mixing of freshwater with the Caspian Seawater. Desalination, 229 (1-3), 118.124 (7 pages).

Kerner, M.; Wallmann, K., (1992). Remobilization events involving $\mathrm{Cd}$ and $\mathrm{Zn}$ from intertidal flat sediments in the
Elbe estuary during the tidal cycle. Estuar. Coastal Shelf Sci., 35 (4), 371-393 (23 pages).

Kozelka, P. B.; Bruland, K. W., (1998). Chemical speciation of dissolved $\mathrm{Cu}, \mathrm{Zn}, \mathrm{Cd}, \mathrm{Pb}$, in Narragansett Bay, Rhode Island. Mar. Chem., 60 (3-4), 267-282 (16 pages).

Laane, R. W. P. M., (1980). Conservative behavior of dissolved organic carbon in the Ems-Dollart estuary and the Western Wadden Sea. Neth. J. Sea Res., 14 (2), 192-199 (8 pages).

Li, Y. H.; Burkhardt, L.; Teroka, H., (1984). Desorption and coagulation of trace elements during estuarine mixing. Geochim. Cosmachim. Acta, 48 (10), 1879-1884 (6 pages).

Mackenzie, F. T., (1975). Sedimentary cycling and the evolution of seawater. In Riley, J. P.; Skirrow, G (Eds.) Chemical Oceanography 1, $2^{\text {nd. }}$ Ed. Academic, 309-364.

Mackenzie, F. T.; Garrels, R. M., (1966). Chemical mass balance between rivers and oceans. Am. J. Sci., 264, 507-525 (6 pages).

Malakootian, M.; Nouri, J.; Hossaini, H., (2009). Removal of heavy metals from paint industries wastewater using Leca as an available adsorbent. Int. J. Environ. Sci. Tech., 6 (2), 183-190 (8 pages).

Mantoura R. F. C.; Mann, S. V., (1979). Dissolved organic carbon in estuaries. in: Severn, R. T.; Dineley, D.; Hawker, L. E. (Eds.) Tidal power and estuary management, Bristol, Scientechnical, 279-286.

Martoura, R. F. C.; Woodward, E. M. S., (1983). Conservative behavior of riverine dissolved organic carbon in the Severn estuary. Chemical and geochemical implications. Geochim. Cosmochim. Acta, 47 (7), 1293-1309 (17 pages).

Matagi, S. V.; Swai, D.; Mugabe, R., (1998). A review of heavy metal removal mechanisms in wetlands. Afr. J. Trop. Hydrobiol. Fish, 8 (1), 23-25 (3 pages).

Mckenna, J. H., (2004). DOC dynamics in a small temperate estuary: Simultaneous addition and removed processes implications on observed non conservative behavior. Estuaries, 27 (4), 604-616 (13 pages).

Meybeck, M., (1988). How to establish and use world budgets of riverine materials. In Lerman, A.; Meybeck, M., (Eds.) Physical and chemical weathering in geochemical cycles, Kluwer, Dordrecht, 247-272.

Meyer, J. L.; Tate, C. M., (1983). The effects of watershed disturbance on dissolved organic carbon dynamics of a stream. Ecology, 64 (1), 33-44 (11 pages).

Moor, R. M.; Burton, J. D.; Williams, P. J. B.; Young, M. L., (1979). The behavior of dissolved organic material, Fe and $\mathrm{Mn}$ in estuarine mixing. Geochim. Cosmochim. Acta, 43 (6), 919-926 (7 pages).

Moyan, M. A.; Hodson, R. E., (1990). Bacterial production on humic and nonhumic components of dissolved organic carbon. Limnol. Oceanogr., 35 (8), 1744-1756 (13 pages).

Nouri, J.; Karbassi, A. R.; Mirkia, S., (2008a). Environmental management of coastal regions in the Caspian Sea. Int. J. Environ. Sci. Tech., 5 (1), 43-52 (10 pages).

Nouri, J.; Mahvi, A. H.; Jahed, G. R.; Babaei, A. A., (2008b). Regional distribution pattern of groundwater heavy metals resulting from agricultural activities. Environ. Geo., 55 (6), 1337-1343 (7 pages).

Paucot, H.; Wollast, R. (1997). Transport and transformation of trace metals in the Scheldt estuary. Mar. Chem., 58 (12), 229-244 (16 pages). 
Regnier, P.; Wollast, R., (1993). Distribution of trace metals in suspended matter of the Scheldt estuary. Mar. Chem., 43 (1-4), 3-19 (17 pages).

Samarghandi, M. R.; Nouri, J.; Mesdaghinia, A. R.; Mahvi, A. H.; Naseri, S.; Vaezi, F., (2007). Efficiency removal of phenol, lead and cadmium by means of $\mathrm{UV} / \mathrm{TiO}_{2} / \mathrm{H}_{2} \mathrm{O}_{2}$ processes. Int. J. Environ. Sci. Tech., 4 (1), 10-25 (16 pages).

Sharp, J. H., (1991). Review of carbon, nitrogen and phosphorus biogeochemistry. Rev. Geophys., 29, 648-657 (10 pages).

Sharp, J. H.; Culberson, C. H.; Church, T. M., (1982). The chemistry of the Delaware estuary. General considerations. Limnol. Oceanogr., 27 (6), 1015-1028 (14 pages).

Shiller, A. M.; Mao, L., (1999). Dissolved vanadium on the Louisiana Shelf: Effect of oxygen depletion. Cont. Shelf. Res., 19 (8), 1007-1020 (14 pages).

Shokovitz, E. R., (1976). Flocculation of dissolved organic and inorganic matter during the mixing river water and seawater. Geochim. Cosmochim. Acta, 40 (7), 831-845 (15 pages).

Shokovitz, E. R.; Boyle, E. A.; Price, N. B. (1977). Removal of dissolved material in the Amazon estuary. Eos. Trans. Am. Geophys. Union, 5, 423-439 (17 pages).

Sillen, L. G., (1961). The physical chemistry of seawater. In Sears, M. (Ed) Oceanography. Am. Assoc. Adv. Sci., 549581 (33 pages).

Troup, B. N.; Bricker, O. P., (1975). Processes affecting the transport of materials from continents to Oceans. in: Church, T. M. (Ed) Marine chemistry in the coastal environment, Am. Chem. Soc., 133-151 (13 pages).
Van den Berg, C. M. G.; Merks, A. G. A.; Duursma, E. K., (1987). Organic complexation and its control of the dissolved concentration of copper and zinc in the Scheldt estuary. Estuar. Coastal. Shelf Sci., 24 (6), 785-797 (13 pages).

Westerlund, S. F. G.; Anderson, L. G.; Hall, P. O. J.; Inverfeldt, A.; Rutgers, Van der Loeff, M.; Sundby, B., (1986). Benthic fluxes of cadmium, copper, nickel, zinc and lead in the coastal environment. Geochim. Cosmochim. Acta, 50 (6), 1289-1296 (8 pages).

Wollast, R. (1988). The Scheldt estuary. in: Salomons, W.; Bayne, B. L.; Duursma, E. K.; Forstner, U. (Eds.) Pollution of the North Sea, An assessment, Springer, Berlin, 183-194.

Zhiqing, L. E.; Jianhu, Z.; Jinsi, C., (1987). Flocculation of dissolved $\mathrm{Fe}, \mathrm{Al}, \mathrm{Mn}, \mathrm{Si}, \mathrm{Cu}, \mathrm{Pb}$ and $\mathrm{Zn}$ during estuarine mixing. Acta Oceanol. Sin., 6 (44), 568-576 (10 pages).

Zvinowanda, C. M.; Okonkwo, J. O.; Shabalala, P. N.; Agyei, N. M., (2009). A novel adsorbent for heavy metal remediation in aqueous environments. Int. J. Environ. Sci. Tech., 6 (4), 425-434 (10 pages).

Zwolsman, J. J. G.; Van Eck, G. T. M.; Van der Weijden, C. H., (1997). Geochemistry of dissolved trace metals (Cadmium, Copper, Zinc) in the Scheldt estuary, Southwestern Netherlands: Impact of Seasonal Variability. Geochim. Cosmochim. Acta, 61 (8), 1636-1652 (17 pages).

Zwolsman, J. J. G.; Van Eck, G. T. M., (1993). Dissolved and particulate trace metal geochemistry in the Scheldt estuary, S. W. Netherlands (Water Column and Sediments). Neth. J. Aquatic Ecol., 27 (2-4), 287-300 (14 pages).

\section{AUTHOR (S) BIOSKETCHES}

Biati, A., Ph.D. Candidate, Department of Environmental Science, Graduate School of the Environment and Energy, Science and Research Branch, Islamic Azad Universty, Tehran, Iran. Email: bayati_id@yahoo.com

Karbassi, A. R., Ph.D., Assistant Professor, Department of Environmental Engineering, University of Tehran. Email: akarbassi@ut.ac.ir

Hassani, A. H., Ph.D., Assistant Professor, Department of Environmental Engineering, Graduate School of the Environment and Energy, Science and Research Branch, Islamic Azad Universty, Tehran, Iran. Email: ahhassani@gmail.com

Monavari, S. M., Ph.D., Assistant Professor, Department of Environmental Science, Graduate School of the Environment and Energy, Science and Research Branch, Islamic Azad Universty, Tehran, Iran. Email: monavarism@yahoo.com

Moattar, F., Full Professor, Department of Environmental Engineering, Graduate School of the Environment and Energy, Science and Research Branch, Islamic Azad University, Tehran, Iran. Email: moattar@yahoo.com

How to cite this article: (Harvard style)

Biati, A.; Karbassi, A. R.; Hassani; A. H.; Monavari, S. M.; Moattar, F., (2010). Role of metal species in flocculation rate during estuarine mixing. Int. J. Environ. Sci. Tech., 7 (2), 327-336. 